\title{
RELATIONSHIP BETWEEN SERUM VITAMIN D AND INSULIN RESISTANCE IN NORMAL WEIGHT AND OVERWEIGHT OR OBESE MEN.
}

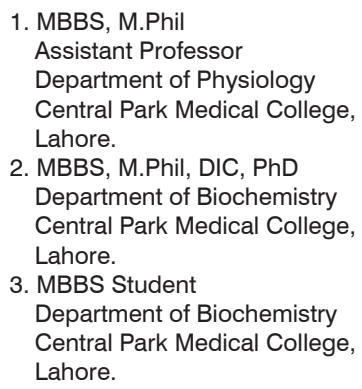

2. MBBS, M.Phil, DIC, PhD Department of Biochemistry Central Park Medical College, Lahore.

3. MBBS Student

Department of Biochemistry Central Park Medical College, Lahore.

Correspondence Address: Dr. Sabiha lqbal A-272 Press Club Housing Society Harbanspura Lahore.

drsabihafarooq@hotmail.com

Article received on: 31/10/2018

Accepted for publication: 17/06/2019

\begin{abstract}
Sabiha Iqbal', Syed Imran Ali Shah², Mirza Zeeshan Sikandar ${ }^{3}$
ABSTRACT: Obesity is a common clinical disorder featuring excessive buildup of body fat. The bioavailability of vitamin $D$ in obese subjects is lowered because of its sequestration in the superfluous fat tissue. Hypovitaminosis $D$ itself is associated with glucose intolerance, insulin resistance, dyslipidemia and hypertension, which are also linked to obesity. Objectives: To compare and correlate serum vitamin D and insulin resistance in controls and overweight / obese males. Study Design: Cross Sectional, Comparative Study. Setting: The study was conducted in the Department of Physiology, Post - Graduate Medical Institute (PGMI) in collaboration with Lahore General Hospital and Central Park Medical College. Period: From $7^{\text {th }}$ June 2018 to $10^{\text {th }}$ Oct 2018. Material and Methods: Eighty male subjects (age range 35-50 years) included in this cross-sectional comparative study were divided into two groups on the basis of BMI; Group I: non-obese (control) BMI $<25 \mathrm{Kg} / \mathrm{m}^{2}(\mathrm{n}=40)$ and Group II: overweight / obese males with $\mathrm{BMI} \geq 25 \mathrm{Kg} / \mathrm{m}^{2}(\mathrm{n}=40)$. Fasting serum vitamin $\mathrm{D}$ ( 25 hydroxy cholecalciferol; 25-OH D, serum insulin and blood glucose levels were measured. Insulin resistance (IR) was estimated from fasting serum glucose levels taken in $\mathrm{mmol} / \mathrm{l}$ and the fasting serum insulin taken in $\mu \mathrm{lU} / \mathrm{ml}$ by using Homeostasis Model Assessment-estimated Insulin Resistance (HOMA-IR index). Results: Group II had lower serum 25-OH vitamin D levels and higher HOMA-IR index than control group. Significant negative correlation was present between serum vitamin $D$ and HOMA-IR. Conclusion: Vitamin D deficiency may promote insulin resistance in overweight or obese individuals.
\end{abstract}

Key words: $\quad$ Insulin Resistance, Obesity, Vitamin D, Glucose Intolerance.

Article Citation: Iqbal S, Shah SIA, Sikandar MZ. Relationship between serum vitamin D and insulin resistance in normal weight and overweight or obese men. Professional Med J 2019; 26(11):1810-1814.

DOI: 10.29309/TPMJ/2019.26.11.237

\section{INTRODUCTION}

Imbalance between energy intake and expenditure leads to a medical ailment known as Obesity characterized by excessive body fat accumulation. Many chronic maladies including diabetes mellitus, cerebrovascular accidents, and cardiovascular diseases can be resultant of obesity. ${ }^{1,2}$ Excess adiposity predisposes to deficiency of vitamin $D$, also known by its chemical name as 25-hydroxy cholecalciferol (25-OH D), by reducing its bioavailability. Vitamin $D$ is sequestered in the accrued adipose tissue because of its lipid-soluble nature. Additionally, obese people tend to commonly consume vitamin-poor diets which may be responsible for the low vitamin $D$ levels seen in obesity. ${ }^{3}$ Advances in research suggested that vitamin $D$ deficiency may be a major contributor to obesity- related ramifications including impaired glucose tolerance (IGT), insulin resistance (IR) eventually leading to type 2 diabetes mellitus. Vitamin D receptor has been found in nearly each tissue type, including those essential for glucose metabolism. Disproportionate distribution body fats observed in obesity increases the serum levels of serum free fatty acids (FFA) which themselves contribute to the development of IR and decline in glucose transport and metabolism in skeletal muscle and fat tissues. ${ }^{4,5}$ Vitamin $D$ has been shown to control insulin synthesis and it decreases the apoptosis of $\beta$ cells of pancreas. It is also involved in the up-regulation of the insulin receptor gene in skeletal muscle, thereby improving the transport of glucose into the muscle cells. ${ }^{6-8}$ The present study investigated the relationship between serum vitamin $D$ levels with insulin resistance in 
obese or overweight adult males selected from the local population.

\section{MATERIALS AND METHODS}

This cross - sectional, comparative study conducted in the department of Physiology, Post Graduate Medical Institute (PGMI) in collaboration with Lahore General Hospital and Central Park Medical College. The study population consisted of 80 male subjects who were segregated into two groups based on a pre-defined body mass index (BMI) criterion. Group I consisted of nonobese men with a BMl less than $25 \mathrm{Kg} / \mathrm{m} 2$ $(n=40)$. This group served as the control group. Under-weight people with BMI less than 19 were excluded. The Group II comprised of overweight / obese males with a BMl more than $25 \mathrm{Kg} / \mathrm{m}^{2}$ $(n=40)$. All subjects recruited for the study were non-diabetics and were not on any medication. After ethical approval, all participants were provided information about the study and consent was obtained from them. Socio-demographic data and anthropometric measures for BMI calculations were recorded on study proforma. $3 \mathrm{ml}$ of fasting blood sample was drawn from each participant using aseptic technique which was then added to gel-activated vacutainers for serum extraction. Serum vitamin D and insulin levels were measured by commercially available enzyme-linked immunosorbent assay (ELISA) kits. Serum glucose was measured by glucose oxidase method. Insulin resistance was calculated from fasting serum glucose levels taken in $\mathrm{mmol} / \mathrm{l}$ and the fasting serum insulin taken in $\mu \mathrm{IU} / \mathrm{ml}$ using homeostasis model assessment-estimated insulin resistance (HOMA-IR) index. The HOMAIR developed by Matthews et al. ${ }^{9}$ has been widely used for the estimation of insulin resistance in researches. Measurement of IR using HOMA-IR is more convenient as compared to euglycemic clamp method.

HOMA - IR $=\frac{\text { Fasting serum glucose } \times \text { Fasting serum insulin }}{22.5}$

\section{RESULTS}

All collected and measured data were entered into SPSS software for statistical analysis. The data were found to be non-normally distributed after applying Shapiro-Wilk test of normality. Nonparametric statistical tests were applied for group comparisons and correlational analysis. Mann Whitney $U$ test was applied to compare data between Group 1 and Group 2 (Table-I). Median (IQR) Serum 25(OH)D of Group I was 65.5 (58.45$74.97) \mathrm{ng} / \mathrm{ml}$ and in obese group II was 18.85 (12.85-34.17) ng/ml. Group I had median (IQR) fasting serum insulin 7.05 (6.43-7.77) $\mu \mathrm{U} / \mathrm{ml}$ whereas group II had 13.25 (11.7-14.6). Median (IQR) of fasting serum glucose Group I was 90 (88-94.75) $\mathrm{mg} / \mathrm{dl}$ and in obese group II was 94 (92-99.5) mg/dl. Median (IQR) HOMA-IR in Group I was 1.61 (1.46-1.83) and in group || was 3.12 (2.65-3.46).

\section{RESULTS}

All collected and measured data were entered into SPSS software for statistical analysis. The data were found to be non-normally distributed after applying Shapiro-Wilk test of normality. Nonparametric statistical tests were applied for group comparisons and correlational analysis. Mann Whitney $U$ test was applied to compare data between Group 1 and Group 2 (Table-I). Median (IQR) Serum 25(OH)D of Group I was 65.5 (58.45$74.97) \mathrm{ng} / \mathrm{ml}$ and in obese group II was 18.85 (12.85-34.17) ng/ml. Group I had median (IQR) fasting serum insulin $7.05(6.43-7.77) \mu \mathrm{U} / \mathrm{ml}$ whereas group II had 13.25 (11.7-14.6). Median (IQR) of fasting serum glucose Group I was 90 (88-94.75) $\mathrm{mg} / \mathrm{dl}$ and in obese group II was 94 (92-99.5) mg/dl. Median (IQR) HOMA-IR in Group I was 1.61 (1.46-1.83) and in group || was 3.12 (2.65-3.46).

\section{- Using Mann Whitney U Test $\star * *$ is considered as very highly significant.}

Using Spearman's correlation coefficient, a significant negative correlation was present between serum 25(OH) D and HOMA-IR in all subjects $($ rho $=-0.769 p=<0.0001 * \star *$ (Figure -1$)$. 


\begin{tabular}{|c|c|c|c|c|c|}
\hline \multirow{2}{*}{ Parameters } & \multirow{2}{*}{ Group I } & \multirow{2}{*}{ Group II } & \multicolumn{2}{|c|}{ Mean rank } & \multirow{2}{*}{$P$-Value } \\
\hline & & & Group I & Group II & \\
\hline $\begin{array}{l}\text { Fasting serum 25(OH)D (ng/ml) } \\
\text { Median (IQR) }\end{array}$ & $\begin{array}{c}65.5 \\
(58.45-74.97\end{array}$ & $\begin{array}{c}18.85 \\
(12.85-34.17)\end{array}$ & 60.50 & 20.50 & $<0.0001^{* * *}$ \\
\hline $\begin{array}{l}\text { Fasting serum insulin }(\mu \mathrm{U} / \mathrm{ml}) \\
\text { Median (IQR) }\end{array}$ & $\begin{array}{c}7.05 \\
(6.43-7.77)\end{array}$ & $\begin{array}{c}13.25 \\
(11.7-14.6)\end{array}$ & 20.50 & 60.50 & $<0.0001^{* * *}$ \\
\hline $\begin{array}{l}\text { Fasting serum glucose (mg/dl) } \\
\text { Median (IQR) }\end{array}$ & $\begin{array}{c}90 \\
(88-94.75)\end{array}$ & $\begin{array}{c}94 \\
(92-99.5)\end{array}$ & 32.25 & 48.78 & $<0.001^{\star *}$ \\
\hline - HOMA-IR Median (IQR) & $\begin{array}{c}1.61 \\
(1.46-1.83)\end{array}$ & $\begin{array}{c}3.12 \\
(2.65-3.46)\end{array}$ & 20.55 & 60.55 & $<0.0001^{* * *}$ \\
\hline
\end{tabular}

Table-I. Group-based comparison of serum 25(OH) D and glycemic parameters

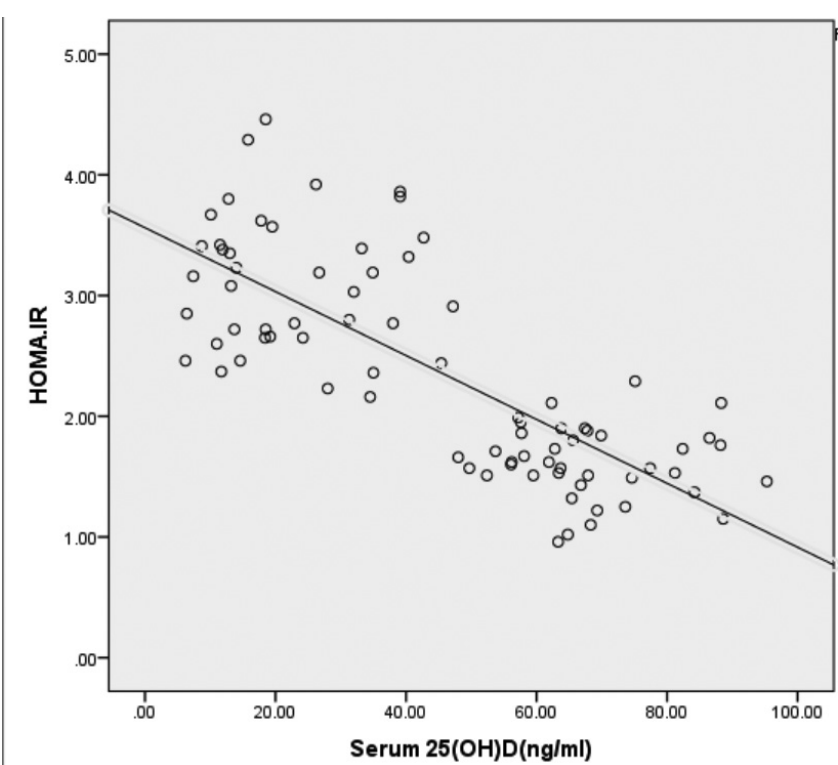

Figure-1. Scatter plot of serum 25(OH) D and HOMA-IR in all subjects

\section{DISCUSSION}

The present study has demonstrated that serum vitamin D levels are significantly lower in individuals with higher BMI which are consistent with results from previous studies. ${ }^{10-12}$ Lower serum vitamin $\mathrm{D}$ levels have also been reported by Roth et al. in otherwise healthy children who were obese as compared to lean children. ${ }^{13}$ Obese patients with metabolic syndrome have also been reported to suffer from hypovitaminosis $D$ as compared to healthy subjects. ${ }^{14,15}$ Furthermore, reduced 25$\mathrm{OH} \mathrm{D}$ levels in obese persons may be attributed to its fat-soluble nature which causes it to be sequestered in fat tissue and its lower dietary intake. ${ }^{16}$ A decreased amount of serum 25-OH D has been shown to increase intracellular calcium in adipocytes which can stimulate lipogenesis, thus predisposing a patient to further weight gain and advancing the risk of diabetes mellitus. ${ }^{17}$ Moreover, treatment of diabetic patients with vitamin-D has been shown positive impact over glycemic control by decreasing insulin resistance. Administration of vitamin $\mathrm{D}$ has also been shown to ameliorate pro-inflammatory markers like C-reactive protein which are typically found in diabetic patients. ${ }^{18}$

The present work has shown that serum insulin levels and HOMA-IR (reflective of insulin resistance) are significantly higher in people with $\mathrm{BMI}>25 \mathrm{~kg} / \mathrm{m}^{2}$. These findings that raised $\mathrm{BMI}$ decreases serum insulin because of decreased vitamin d receptors due to obesity is in accordance with several studies carried out previously. ${ }^{19}$ Increased free fatty acid levels (FFA) in obesity result in insulin resistance by inhibiting the transport of glucose into the cell, its phosphorylation and oxidation. ${ }^{20}$ Insulin produced under a condition of insulin resistance does not act as efficiently as in the normal insulin-sensitive state, leading to an ineffective cellular utilization of glucose which may lead to immunity backfire. Beta cells in the pancreas consequently increase their production of insulin, further contributing to a high blood insulin level. ${ }^{21}$

Low levels of serum vitamin $D$ seen in obesity may lead to insulin resistance as depicted by the negative correlation observed between serum 25-OH D and HOMA-IR in the current study. This result is comparable to the study of Pham, 2015. In his longitudinal study of non-diabetic adults, he found that higher baseline and greater temporal increases in serum 25(OH)D concentrations were associated with a reduced risk for insulin 
resistance. ${ }^{22}$ In another study by Moore et al., a cross-sectional analysis of Jerusalem birth cohort showed a moderate inverse relation between serum vitamin $D$ concentration and logarithm of HOMA-IR in men. No such findings were observed for women. ${ }^{23}$ Our study also involved male subjects and future work employing women from the local population may give useful data for comparisons with other studies conducted elsewhere. A study by Rajakumar et al., failed to demonstrate an association between serum vitamin $D$ levels and HOMA-IR. These contradictory results may be explained by the limited number of subjects, the wider age range of the participants and the differences in the methods for assessment of insulin sensitivity. ${ }^{24}$

\section{CONCLUSION}

The results from the present study highlight a potentially beneficial role of serum $25-\mathrm{OH}$ D in decreasing insulin resistance. Lower levels of serum 25-OH D increase blood glucose levels because of its ineffective utilization and increase serum insulin levels by stimulation of beta cells of pancreas. Thus, vitamin D deficiency over a certain time period may result in the development of type II diabetes mellitus. The possible therapeutic utility of vitamin $D$ in prevention and/ or management of diabetes mellitus needs to be explored in future studies.

\section{ACKNOWLEDGEMENT}

We are grateful to Dr. A.S. Chughtai, Dean Central Park Medical College for his support and guidance.

\section{CONFLICT OF INTEREST}

The authors declare no conflict of interest.

Copyright@ 17 June, 2019.

\section{REFERENCES}

1. Moustafa JS, Froguel P. From obesity genetics to the future of personalized obesity therapy. Nat. Rev Endocrinol. $2013 \mathrm{Jul} ;$ 9(7):402.

2. Yao Y, Zhu L, He L, Duan Y, Liang W, Nie Z, Jin Y, Wu X, Fang $Y$. A meta-analysis of the relationship between vitamin D deficiency and obesity. Int J Clin Exp Med. 2015; 8(9):14977.
3. Cunha KA, Magalhães El, Loureiro LM, Sant'Ana LF, Ribeiro $A Q$, Novaes JF. Calcium intake, serum vitamin D and obesity in children: Is there an association? Rev Paul Pediatr. 2015; 33(2):222-9.5.

4. Cruz KJ, de Oliveira AR, Pinto DP, Morais JB, da Silva Lima F, Colli C, Torres-Leal FL, do Nascimento Marreiro $D$. Influence of magnesium on insulin resistance in obese women. Biol Trace Elem Res. 2014; 160(3):30510.

5. Jung UJ, Choi MS. Obesity and its metabolic complications: The role of adipokines and the relationship between obesity, inflammation, insulin resistance, dyslipidemia and nonalcoholic fatty liver disease. Int J Mol Sci. 2014; 15(4):6184-223.

6. Cândido FG, Bressan J. Vitamin D: Link between osteoporosis, obesity, and diabetes?. Int $J$ Mol Sci. $2014 ; 15(4): 6569-91$.

7. Matyjaszek-Matuszek $B$, Lenart-Lipińska $\quad M$, Woźniakowska E. Clinical implications of vitamin D deficiency. Prz menopauzalny= Menopause rev. 2015; 14(2):75.

8. Wolden-Kirk H, Overbergh L, Christesen HT, Brusgaard K, Mathieu C. Vitamin D and diabetes: its importance for beta cell and immune function. Mol Cell Endocrinol. $2011347(1-2): 106-20$.

9. Matthews DR, Hosker JP, Rudenski AS, Naylor BA, Treacher DF, Turner RC. Homeostasis model assessment: insulin resistance and $\beta$-cell function from fasting plasma glucose and insulin concentrations in man. Diabetologia. 1985; 28(7):4129.

10. Vinh qu $\square$ c L $\square \square$ ng K, Nguy $\square$ n LT. The beneficial role of vitamin $D$ in obesity: Possible genetic and cell signaling mechanisms. Nutr J. 2013 Dec; 12(1):89.

11. Rodríguez $\square$ Rodríguez E, Navia B, López $\square$ Sobaler AM, Ortega RM. Vitamin D in overweight/obese women and its relationship with dietetic and anthropometric variables. Obesity. 2009; 17(4):778-82.

12. Vimaleswaran KS, Berry DJ, Lu C, Tikkanen E, Pilz S, Hiraki LT, Cooper JD, Dastani Z, Li R, Houston DK, Wood AR. Causal relationship between obesity and vitamin D status: bi-directional Mendelian randomization analysis of multiple cohorts. PLOS Med. 2013; 10(2):e1001383.

13. Roth CL, Elfers C, Kratz M, Hoofnagle AN. Vitamin D deficiency in obese children and its relationship to insulin resistance and adipokines. J Obes. 2011; 2011. 
14. Moy FM, Bulgiba A. High prevalence of vitamin D insufficiency and its association with obesity and metabolic syndrome among Malay adults in Kuala Lumpur, Malaysia. BMC public health. 2011; 11(1):735.

15. Lu L, Yu Z, Pan A, Hu FB, Franco OH, Li H, Li X, Yang $X$, Chen $Y$, Lin X. Plasma 25-hydroxyvitamin D concentration and metabolic syndrome among middle-aged and elderly Chinese individuals. Diabetes care. 2009; 32(7):1278-83.

16. Holick MF, Binkley NC, Bischoff-Ferrari HA, Gordon CM, Hanley DA, Heaney RP, Murad MH, Weaver CM. Evaluation, treatment, and prevention of vitamin D deficiency: an Endocrine Society clinical practice guideline. J Clin Endocrinol Metab. 2011; 96(7):191130 .

17. Takiishi T, Gysemans C, Bouillon R, Mathieu C. Vitamin D and diabetes. Rheum Dis Clin North Am. 2012; 38(1):179-206.

18. Giulietti A, van Etten E, Overbergh L, Stoffels K, Bouillon R, Mathieu C. Monocytes from type 2 diabetic patients have a pro-inflammatory profile: 1 , 25-Dihydroxyvitamin D3 works as anti-inflammatory. Diabetes Res Clin Pract. 2007; 77(1):47-57.

19. Barseem NF, Helwa MA. Homeostatic model assessment of insulin resistance as a predictor of metabolic syndrome: consequences of obesity in children and adolescents. Gaz Egypt Paediatr Assoc. 2015; 63(1):19-24.
20. Boden G. Obesity and free fatty acids. Endocrinol Metab Clin North Am. 2008; 37(3):635-46.

21. Chiu HK, Tsai EC, Juneja R, Stoever J, Brooks-Worrell $B$, Goel A, Palmer JP. Equivalent insulin resistance in latent autoimmune diabetes in adults (LADA) and type 2 diabetic patients. Diabetes Res Clin Pract. 2007; $77(2): 237-44$.

22. Pham TM, Ekwaru JP, Loehr SA, Veugelers PJ. The relationship of serum 25-hydroxyvitamin $D$ and insulin resistance among nondiabetic Canadians: $A$ longitudinal analysis of participants of a preventive health program. PLoS One. 2015; 10(10):e0141081.

23. Moore A, Hochner $H$, Sitlani CM, Williams MA, Hoofnagle AN, De Boer IH, Kestenbaum B, Siscovick DS, Friedlander Y, Enquobahrie DA. Plasma vitamin D is associated with fasting insulin and homeostatic model assessment of insulin resistance in young adult males, but not females, of the Jerusalem Perinatal Study. Public Health Nutr. 2015; 18(7):132431.

24. Rajakumar K, de las Heras J, Lee S, Holick MF, Arslanian SA. 25-Hydroxyvitamin D concentrations and in vivo insulin sensitivity and $\beta$-cell function relative to insulin sensitivity in black and white youth. Diabetes Care. 2012; 35: 627-633.

\begin{tabular}{|c|c|c|c|}
\hline \multicolumn{3}{|c}{ AUTHORSHIP AND CONTRIBUTION DECLARATION } \\
\hline Sr. \# & Author(s) Full Name & \multicolumn{1}{|c|}{ Contribution to the paper } & Author(s) Signature \\
\hline 1 & Sabiha lqbal & $\begin{array}{l}\text { Conception, Study design, } \\
\text { Data collection, Data analysis, } \\
\text { Statistics, Resutls and its } \\
\text { interpretation, article writing } \\
\text { and critical review. } \\
\text { Study design, Data collection, } \\
\text { Dataanalysis, resutls and its } \\
\text { interpretation, article writing } \\
\text { and critical review. } \\
\text { Data collection, Data analysis, } \\
\text { and article writing. }\end{array}$ \\
\hline 3 & Syed Imran Ali Shah & Mirza Zeeshan Sikandar \\
\hline
\end{tabular}

